\title{
Wildland fire typologies and extreme temperatures in NE Spain
}

\author{
Adrián Cardil, David Merenciano, \\ Domingo Miguel Molina-Terrén
}

\begin{abstract}
Understanding instrumental factors dealing with the development of large wildland fires is a need. Fire spread typologies and extreme temperature days were studied in the 1978-2012 period in Aragón (NE Spain). Temperature was examined at $850 \mathrm{hPa}$ to characterize the low troposphere state and wildfires were grouped in three fire spread typologies: convective fires, wind-driven fires and topography-driven fires. The analysis of wildland fire propagation typologies revealed that convective fires burned the majority of total area burned, resulting in the larger and the most closely typology related to high temperature days (HTDs). Drought Code (DC) correlation with HTDs and wildland fire size was weak.
\end{abstract}

\section{Keywords: Wildland Fire, Fire Spread Patterns, Forestry, Heat Waves, Climate Change}

\section{Introduction}

Southern European countries like Spain have many wildland fires each year, causing enormous losses in terms of human lives, environmental damage and economic disruptions (Pereira et al. 2011, Salis et al. 2013, San Miguel-Ayanz et al. 2013). Over the last years wildland fires became more and more extreme and usually exceeding firefighting capabilities (Miralles et al. 2010). Frequently, simultaneous wildland fires occur and fire agencies collapse while trying to both suppress extreme-behavior fires and provide safety for firefighters and citizens.

Understanding instrumental factors dealing with the development of large wildland fires is a need. Climate/weather, fuels, and people influence fire spread and behavior (Flannigan et al. 2009, Turco et al. 2014). Climate-change projections for the Mediterranean Basin show a higher variability in weather conditions and an increase in extreme weather events, with longer, more frequent, and even more intense heat weaves (Moriondo et al. 2006, Diffenbaugh et al. 2007, Giorgi \& Lionello 2008, Regato 2008, Giannakopoulos et al. 2009, Barriopedro et al. 2011). Summer heat waves or high temperature days (HTDs, short periods with very hot days and very low air humidity) will grow in number and

intensity due to climate change (Regato 2008, Giannakopoulos et al. 2009), increasing the probability of main wildland fire (MWF) occurrence (Cardil et al. 2014a). Although both climate and weather are considered the principal modeling factors (Flannigan et al. 2009, Trouet et al. 2009), further considerations must be taken into account when studying a particular region. For example, in Aragón agricultural abandonment and increasing fuel load are serious concerns regarding large wildland fires.

Dominant fire spread patterns are related to specific synoptic weather conditions, topography, or fuels, determining fire behavior and thus fire suppression opportunities (Castellnou et al. 2009). Depending on the spread scheme, fires have been usually classified into three different fire spread patterns according to the dominant spread factor: topography (topography-driven fires), wind (wind-driven fires) or fuel accumulation that could be related to convective fires (Lecina-Diaz et al. 2014, Duane et al. 2015). Topography-driven fires are characterized by local convective winds caused by differential solar heating of the land surface. Fire varies direction along the slopes and is supported by local winds. Fire behavior is usually higher in daytime due to the alignment between slope and wind.

School of Agrifood and Forestry Science and Engineering, University of Lleida (Spain)

@ Adrián Cardil (adriancardil@gmail.com)

Received: Dec 09, 2015 - Accepted: Aug 16, 2016

Citation: Cardil A, Merenciano D, Molina-Terrén DM (2016). Wildland fire typologies and extreme temperatures in NE Spain. iForest 10: 9-14. - doi: 10.3832/ifor1939-009 [online 2016-11-01]

Communicated by: Davide Ascoli
Wind-driven fires are characterized by synoptic winds. Both fire speed and direction do not change in a significant way during the episode. Wind brings the flame closer to fresh fuel, thus accelerating spread in the wind direction (Rothermel 1983) owing to radiation and forced convection heat transfer (Anderson 1969). Convection or plume driven fires are related to very high fuel loads with low fuel moisture. Fire behavior is usually extreme with massive spotting fires. Fire generates a large amount of heat and convection setting their fire behavior. The hot air mass situated on top of the fire rises by convection, and new cold drafts enter the fire area, reactivating fire activity and increasing fire intensity (Duane et al. 2015).

Finding forecast tools to identify fire spread patterns (fire typologies) and MWF occurrence is frequently very difficult (Vega-García \& Chuvieco 2006, Eastaugh \& Vacik 2012, Arpaci et al. 2013).The aim of this study is to analyze whether dominant fire spread patterns are more likely to occur under HTD or non-HTD conditions or are correlated to Drought Code (DC) index. MWFs were classified attending to its main spreading factor (convection, topography or wind), analyzing their relative importance in terms of fire number, burned area and fire size in Aragón (NE Spain) and studying whether DC index or HTDs could be precise indicators to identify fire spread patterns, especially convective fires.

\section{Methods}

\section{Study area}

This work focuses on the Spanish region of Aragón (Fig. 1). Located in the northeastern part of the country, Aragón comprises three provinces: Teruel, Huesca, and Zaragoza. Aragón is the fourth largest region in Spain $\left(47,719 \mathrm{~km}^{2}, 9.4 \%\right.$ of the total area of the country). The population 


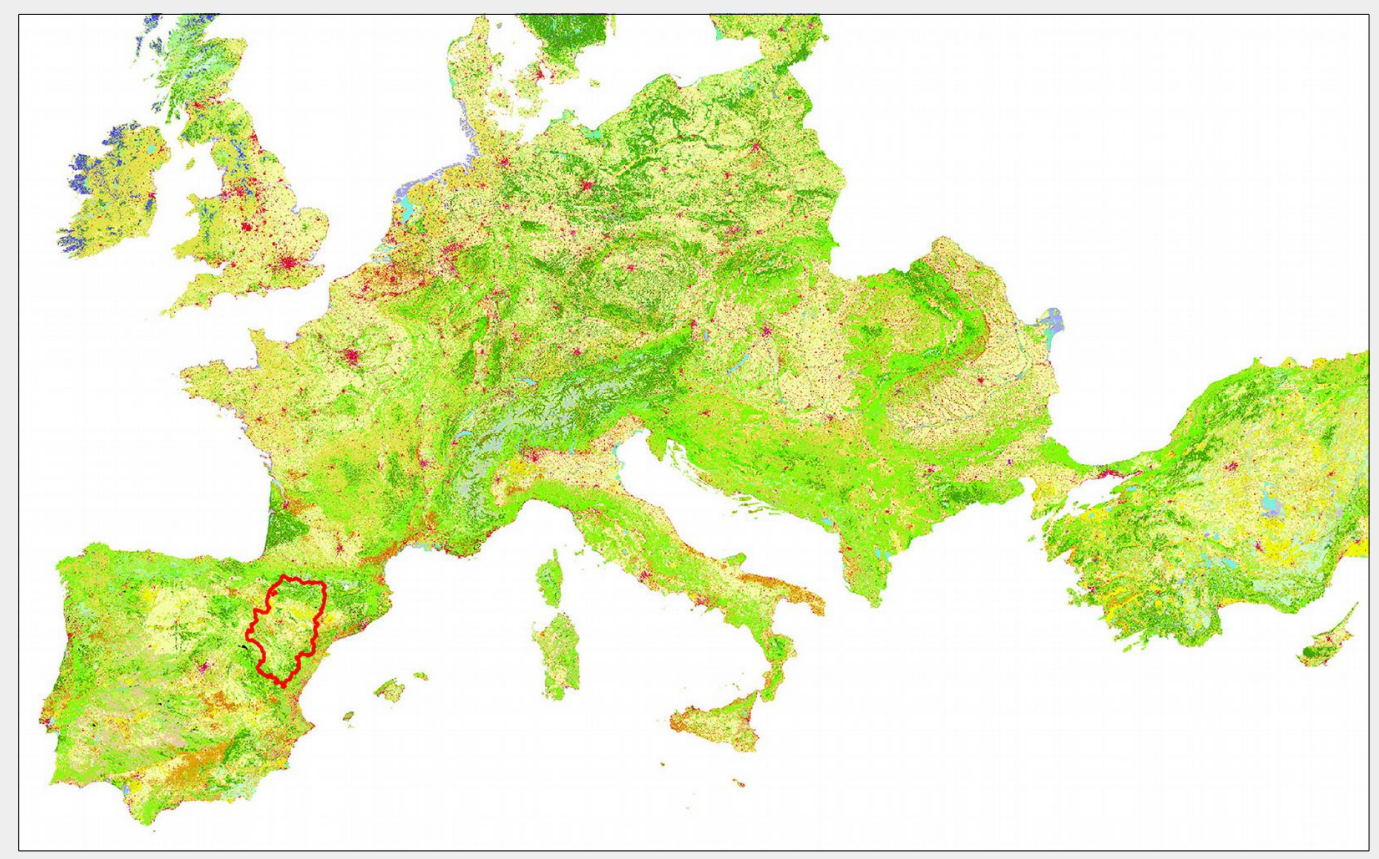

Fig. 1 - Geographic location of Aragón in Europe.

density is low (28.3 people $\mathrm{km}^{-2}$ ).

Aragón is part of the most susceptible European area to a significant increase in extreme-temperature events and to sustain some of the most significant impacts (Giorgi 2006, Giannakopoulos et al. 2009). The region is bordered by two mountain chains: the Pyrenees (maximum altitude $3404 \mathrm{~m}$, Aneto) and the Iberian System (maximum altitude $2314 \mathrm{~m}$, Moncayo), and crossed by a major river (Ebro). The environment of Aragón varies from high mountains in the north-central Pyrenees, with glaciers, to steppe or semi-arid areas such as Monegros. The climate in Aragón can be generally regarded as a Mediterranean climate with continental tendencies; however, the complex topography influences it generating local climate variability. The mean annual temperature ranges from 22.5 ${ }^{\circ} \mathrm{C}$ in the Ebro valley to $5{ }^{\circ} \mathrm{C}$ in the highest areas of the Pyrenees. Moreover, the average annual rainfall varies ranging from $1800 \mathrm{~mm}$ in the Pyrenees to $300 \mathrm{~mm}$ in the valley (AEMET 2012). Regarding wildland vegetation, it is strongly conditioned by relief and climate. Upland forests present several tree species such as pines (Pinus sylvestris, $P$. uncinata, $P$. nigra, $P$, halepensis), fir (Abies alba), beech (Fagus sylvatica), Maples (Acer sp.) and oaks (Quercus sp.), shrubs and meadows. In the Ebro valley, the most common tree species are oaks and junipers (Juniperus oxycedrus, J. comunis and J. thurifera), which are replaced by shrubs and grasslands in degraded areas.

Main wildland fires and fire typologies

In this work, we have defined main wildland fires (MWF) as those burning over 60 ha. We selected that interval because whilst they represented just $2.62 \%$ of the total number of fires for the period 19782012 , they accounted for $85.35 \%$ of the total area burned in Aragón. It is known that in many Mediterranean regions a restricted number of main wildland fires accounts for a large amount of the total burned area (Salis et al. 2013). In the analyzed period, 223 MWFs burned almost 148,000 ha in Aragón (NE Spain) during the summer season (June-September, when wildland fires mostly happen). Analyzed data were extracted from the historical wildland fire databases provided by the Wildland Fire National Statistics (EGIF) of the Spanish Ministry of Environment and Rural and Marine Affairs (MARM), a national administration in charge for compiling statistics, backing up regional firefighting actions, and coordinating fire suppression at the national level. This comprises the wildland fire reports sent to the MARM by the FireFighting and Forest Management Services of all the Spanish regions.

We used Pettitt's test to detect changes in burned area in the study period. It is a non-parametric test to detect abrupt changes in the mean of the distribution of the variable of interest. Although the method did not find any significant shift at a point of the study period, we split the study period in two time intervals (19781993 and 1994-2012) addressing differences in HTD patterns to explore changes in terms of fire number, burned area and fire typologies. The second time interval includes the years with the highest values of number of HTDs (1994, 2003, 2009, 2012 Cardil et al. 2013), large fires with extreme fire behavior occurred in Aragón and other regions as Catalonia or Valencia Community in these years and the annual number of HTDs was significantly higher than in the first period. Additionally, the periods were different due to socioeconomic, land abandonment and fire suppression changes. In the second period, land abandonment was widespread and the fuel load and large wildland fire occurrence with extreme fire behavior increased. Moreover, fire agencies invested heavily in suppression resources and improved remarkably their training and fire behavior knowledge.

MWFs were classified into three different fire spread patterns: topography-driven fires, wind-driven fires and convective fires (Lecina-Diaz et al. 2014, Duane et al. 2015). Lázaro et al. (2014) and Lázaro-Palacios et al. (2016) made a characterization of fire typologies in this region based on synoptic weather condition analysis across the study area. However, we chose to simplify to only three fire typologies following other works (Duane et al. 2015) and fires were classified according to synoptic weather conditions at $500 \mathrm{hPa}$ air pressure level and a relief in particular for each fire (Lázaro-Palacios et al. 2016). Additionally, historical mapped fires were checked towards this categorization in accordance to the main spreading factor, identifying weather conditions that explain their behavior. Overall, 174 out 223 (78\%) MWFs were classified in the studied period; therefore 49 MWFs were not classified due to a lack of enough data to check the categorization (local weather data, fire perimeter, etc).

\section{High temperature days}

We defined all days from 1978 to 2012 from June $1^{\text {st }}$ to September $30^{\text {th }}$ (i.e., summer season) as a High Temperature Day when air temperature at $850 \mathrm{hPa}$ was equal or higher than $20^{\circ} \mathrm{C}$, as this temperature corresponds approximately to the percentile $95^{\text {th }}$ in the summer season for that region (Cardil et al. 2014a). The use of the $95 \%$ percentile helps capture the different implications of extreme temperatures for human health, natural vegetation, energy systems, and environmental disturbances in different locations (Cardil et al. 2014b). We selected the temperature at $850 \mathrm{hPa}$ 
because it is commonly used to examine past fire weather and forecast fire weather (Millán et al. 1998, Trigo et al. 2005, GarcíaOrtega et al. 2011). At this air pressure (850 $\mathrm{hPa}$ ), we obtained a regional reportage of the temperature which is adequately close to the Earth surface to allow the low troposphere state to be characterized. Additionally, employing measurements at this air pressure we avoided some of the problems that affect near surface reanalysis variables (Ogi et al. 2005, Trigo et al. 2005). Reanalysis data from the National Centers for Environmental Prediction and the National Center for Atmospheric Research (NCEP/ NCAR) were used to characterize the high temperature days (Kalnay et al. 1996) on a synoptic scale.

\section{Drought code}

Drought Code (DC) is a measurement of long-term dryness in fuels. Although it does not reflect the probability of fire occurrence by itself, DC could be useful in predicting large wildland fire occurrence, extreme fire behavior and the consumption of large fuels (Minnesota Department of Natural Resources 2013). DC integrates by design past weather over a longer period than other components of the Canadian Forest Fire Behavior System that were easily influenced by short term changes in weather conditions (Turner 1972). Even so, the Canadian DC is sensitive to daily precipitation, such that one rainfall can significantly affect the value of the index for many days after precipitation (Flannigan et al. 2009). This index is used by itself by several regional Forest Service and Fire Suppression agencies in NE Spain (Lázaro-Palacios et al. 2016), and we tested if it provides reliable forecast of adverse fire weather conditions in terms of fire typologies in the study area.

In this study, we analyzed DC values for MWFs in the 1978-2012 period occurred in Aragón. DC values were assigned in 163 out of 223 wildland fires $(73.1 \%$ ) due to lack of detailed weather data.

\section{Statistical analysis}

We used non-parametric tests (KruskalWallis and Mann-Whitney) to analyze trends and the influence of HTDs and DC index on fire typologies, fire number, burned area and fire size in the 1978-2012 period, analyzing if some fire typologies were linked to extreme temperature conditions or high values of DC index.

\section{Results}

Wind-driven fire typology was the most frequent in the 1978-2012 period with 69 fires, burning 26,746 ha. However, 39 convective fires burned the majority of the total area burned $(81,173$ ha, $59.8 \%$ of the total area burned). The average fire size was significantly higher in convective fires (2624.9 ha), followed by wind-driven fires (433.2 ha) and topographic fires (186.3 ha). Fire number, burned area and average fire

Tab. 1 - Number of fires, burned area and average fire size in the three fire typologies (convective fires, topography and wind-driven fires) in 1978-1993 and 1994-2012 periods under HTD and non-HTD. Mean values in a column in each wildland fires categories followed by the same letter are not significantly different at $95 \%$ significance level.

\begin{tabular}{|c|c|c|c|c|c|c|c|}
\hline \multirow{2}{*}{$\begin{array}{l}\text { Fire } \\
\text { typology }\end{array}$} & \multirow{2}{*}{$\begin{array}{l}\text { Day } \\
\text { condition }\end{array}$} & \multicolumn{2}{|c|}{ Fire number } & \multicolumn{2}{|c|}{ Burned area (ha) } & \multicolumn{2}{|c|}{ Average fire size (ha) } \\
\hline & & $\begin{array}{l}1978- \\
1993\end{array}$ & $\begin{array}{l}1994- \\
2012\end{array}$ & $\begin{array}{l}1978- \\
1993\end{array}$ & $\begin{array}{l}1994- \\
2012\end{array}$ & $\begin{array}{l}1978- \\
1993\end{array}$ & $\begin{array}{l}1994- \\
2012\end{array}$ \\
\hline \multirow{3}{*}{$\begin{array}{l}\text { Convective } \\
\text { fires }\end{array}$} & HTD & 13 & 19 & 15094 & 56384 & 1161 & 2967 \\
\hline & Non-HTD & 4 & 3 & 3148 & 6747 & 787 & 2249 \\
\hline & Total & \multicolumn{2}{|c|}{39} & \multicolumn{2}{|c|}{81373} & \multicolumn{2}{|c|}{$2624.9^{\mathrm{a}} \pm 285.7$} \\
\hline \multirow{3}{*}{$\begin{array}{l}\text { Topography- } \\
\text { driven fires }\end{array}$} & HTD & 12 & 13 & 1559 & 2360 & 130 & 182 \\
\hline & Non-HTD & 27 & 13 & 5150 & 1549 & 191 & 119 \\
\hline & Total & \multicolumn{2}{|r|}{65} & \multicolumn{2}{|c|}{10618} & \multicolumn{2}{|c|}{$186.3^{b} \pm 210.7$} \\
\hline \multirow{3}{*}{$\begin{array}{l}\text { Wind-driven } \\
\text { fires }\end{array}$} & HTD & 9 & 16 & 2444 & 3696 & 271 & 231 \\
\hline & Non-HTD & 28 & 16 & 11460 & 9146 & 409 & 571 \\
\hline & Total & \multicolumn{2}{|c|}{69} & \multicolumn{2}{|c|}{26746} & \multicolumn{2}{|c|}{$433.2^{b} \pm 202.0$} \\
\hline \multirow[t]{3}{*}{ No data } & HTD & 12 & 0 & 4305 & 0 & 358 & - \\
\hline & Non-HTD & 32 & 5 & 11487 & 1697 & 358 & 340 \\
\hline & Total & \multicolumn{2}{|c|}{49} & \multicolumn{2}{|c|}{17489} & \multicolumn{2}{|c|}{$356.9^{\mathrm{b}} \pm 386.8$} \\
\hline
\end{tabular}

size in the study period in each fire typology in 1978-1993 and 1994-2012 periods under HTDs and non-HTDs are shown in Tab. 1. Additionally, wildland fires in Aragón from 1978 to 2012 characterized by the main spreading factor are shown in Fig. 2.

Changes in the fire number, burned area and fire size were studied in all fire spread

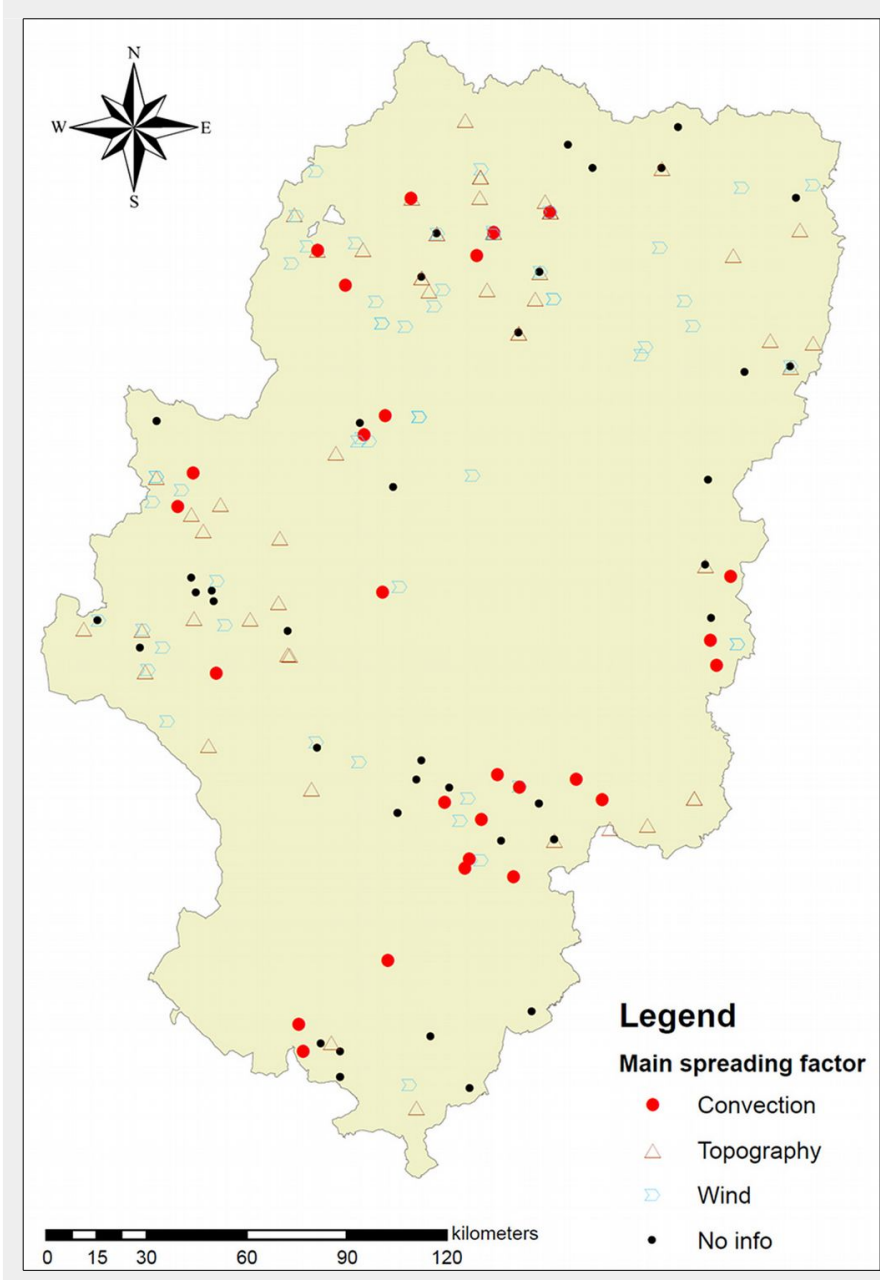

Fig. 2 - Wildland fires in Aragón from 1978 to 2012 characterized by the main spreading factor. 


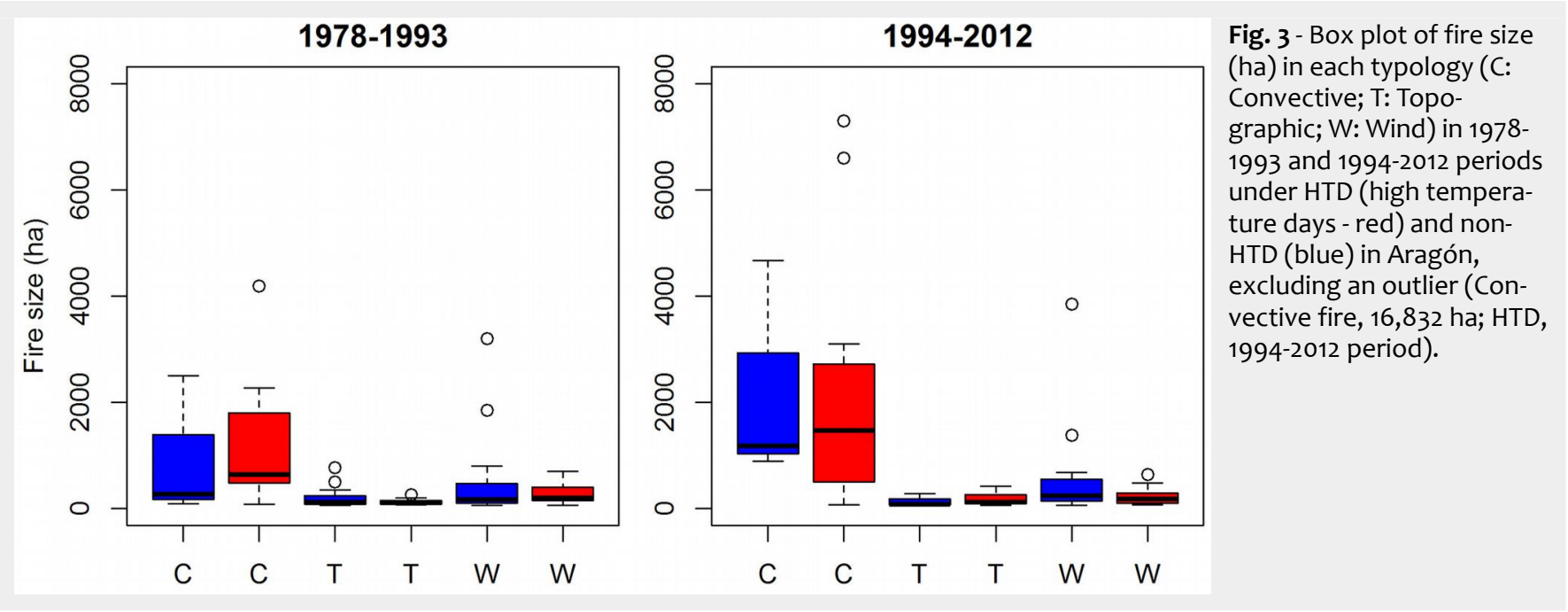

ing 71,478 ha ( $87 \%$ of the total area burned by convective fires). They did not increase significantly in terms of annual fire number, but burned area increased in a significant way in the second period with 56,384 burned ha (more than 3 times - Tab. 1, Fig. 3). Average fire size also increased significantly $(p<0.01)$ in both periods and both weather conditions.

\section{Topography-driven fires}

Sixty-five MWFs burned 10,618 ha from 1978 to 2012 (7.8\% of the total burned area in the study period). Therefore, annual burned area in this typology was significantly lesser than in convective fires. Most of the burned area in this typology occurred under non-HTDs in the 1978-1993 period, although we found a significant decrease in both fire number and burned area under non-HTDs in the second period.

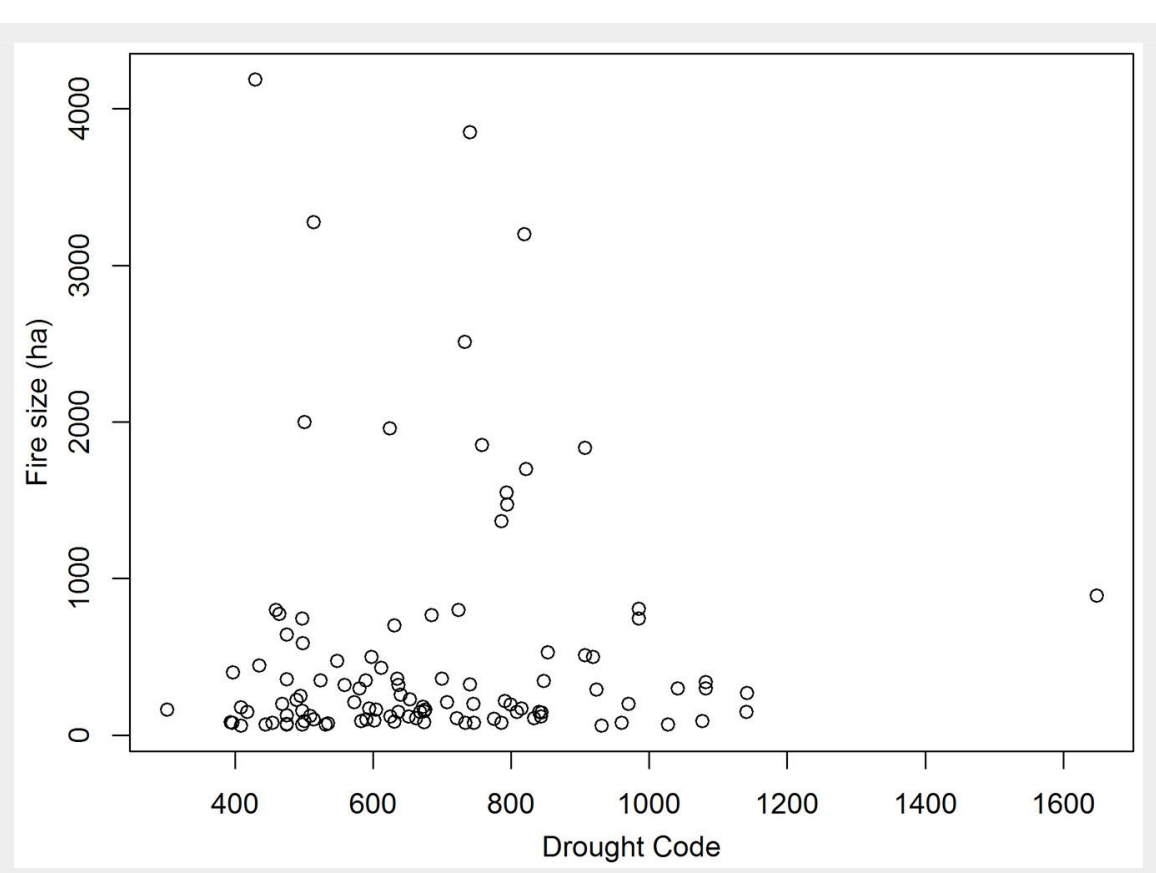

Fig. 4 - Drought Code scatter diagram, showing DC values and fire size (ha), excluding an outlier (700; 16.832).
Considering topography-driven fires under HTDs, we did not observe a reduction in both fire number and burned area in the study period (Tab. 1).

\section{Wind-driven fires}

The majority of fires and the largest burned area were observed under nonHTDs. Both indicators in this typology seem to decrease under non-HTDs and increase under HTDs between the two studied periods, although these trends were not significant statistically at $95 \%$ significance level.

\section{Drought code}

Average DC value for MWFs in the study period was found to be slightly higher for non-HTD (684.41) than for HTD days (661.49); however, this trend was not found to be statistically significant. Fig. 4 shows the scatter diagram of all fires, including fire size and DC. The statistical analysis showed that Drought Code is not a precise indicator, since it does not correlate to fire size in the whole set of fires studied. Considering fire typologies, no significant differences were found in terms of DC, though its value was higher in convective fires (771) than topographic and winddriven fires (662 and 673 respectively).

\section{Discussion and conclusions}

Typically, low humidity, high temperatures and strong winds near the ground surface are considered the major determinants in fire weather forecasting (Cardil et al. 2014a), whereas meteorological indexes evaluating specific changes in the meteorological conditions are often unavailable for fire weather forecasting agencies (Crimmins 2006, Charney \& Keyser 2010). Moreover, the selection of an index that is effectively representative over large heterogeneous areas, or simply the choice of the most appropriate index, is frequently very difficult (Vega-García \& Chuvieco 2006, Eastaugh \& Vacik 2012, Arpaci et al. 2013). The aims of this study were: (i) to determine whether the $D C$ index or the frequency of high temperature days (HTD) could be used as precise indicators of potentially dangerous situations regarding fire risk and fire typologies (specially convective fires), linked to extreme weather conditions; (ii) to discuss the need of an adaptive forest management to prevent the largest and most virulent fires under a climate change scenario in the next decades.

Although wind-driven fire typology was the most frequent (69 fires), convective fires burned the majority of the total burned area (60\% of total burned area approximately) and their average fire size was significantly higher than that of topography and wind-driven fires. Convective fires did not significantly increase in terms of annual fire number in the study period, but the burned area significantly increased in the second period with 56,384 burned ha (3 times larger than in the first period). 
Moreover, fire size significantly increased in both periods. However, the influence of the worst years in terms of burned area (1994 and 2009) was meaningful in the results. Multiple convective wildland fires burning under HTD conditions simultaneously caused disastrous consequences $(50,208$ ha in convective fires $-96 \%$ of this total burned area under HTDs). Including 1994 in the first period would change the burned area in both studied periods in 29,991 ha (burned area in 1994). However, excluding 1994 from the analysis, average fire size would be significantly higher in 1995-2012 period (2,071 ha) than in 19781993 period ( $1,073 \mathrm{ha})$ and the same for burned area (33,139 vs. 18,242 ha). Therefore, it seems that convective fires could be more frequent in last years of the study period. This could be related to two main factors: (i) the increase in the annual number of HTDs; and (ii) the agricultural abandonment. It is key to remark that convective fires were the larger and fire typology most closely related to HTDs. Most of convective fires occurred under HTDs (more than $80 \%$ in terms of fire number and burned area). Additionally, the annual number of HTDs increased significantly in the study period in Aragón (Cardil et al. 2013). This conspicuous increase could be part of the process detailed by Giannakopoulos et al. (2009), who determined that in areas like Spain an increase in the occurrence of hot days and heat weaves is expected for the next decades. Paying attention to that change will be especially important, since more frequent HTDs will lead to a significant decrease in air humidity and fuel moisture (Cardil et al. 2013), and then to the potential for extreme fire behavior (Cardil et al. 2014a) and convective fire occurrence. The agricultural abandonment is the other factor to be considered. Fuel loads and continuity increased in last 40 years (Vega-García \& Chuvieco 2006), influencing extreme fire behavior and the development of convective fires (Duane et al. 2015). Forest management should be active to protect areas against convective fires as extreme weather conditions are expected to occur more frequently (Giannakopoulos et al. 2009), and fuel loads and continuity are very high in the present. Therefore, new measures regarding fuels should be considered (prescribed burning or silvicultural treatments) by fuel management plans taking into account critical points, i.e., fuel continuity/load and dominant fire spread patterns (Duane et al. 2015).

Both burned area and fire number were reduced under non-HTDs in all fire typologies in both study periods, but not under HTDs, especially when convective fires were considered. Huge investments in fire suppression technology as well as better knowledge of fire behavior and past events has led to a more efficient and faster suppression fires under non-HTDs. However, fires burning under HTD conditions are generally very intense and extreme, exceeding the fire suppression capacity of the emergency management services in most cases, so neither better technology nor more qualified personnel are effective.

DC correlation with fire size did not show a good fit and the index did not discriminate among any fire spread typology, although convective fires showed higher values of this index. This fact reinforces the initial supposition that Drought Code should no longer be used to identify potentially extreme weather conditions. Due to the complexity of drought processes, no single index has been able to adequately capture the intensity and severity of drought and its potential impacts (Heim 2002). In contrast, the ability to discern between HTD and non-HTD could be very useful to identify days with high fire risk and convective fire occurrence.

\section{Acknowledgements}

We are appreciative to ForBurn project (Spanish Ministry of Economy and Competitiveness AGL2012-40098-C03-01). We thank Miguel Lázaro for providing his work, which is a very complete characterization of fire typologies in the analyzed region.

\section{References}

AEMET (2012). Iberian climate atlas. Air temperature and precipitation (1971-2000). State meteorological Agency of Spain and Department of Meteorology and Climatology of the Institute of Meteorology, Portugal. Ministerio de Medio Ambiente y Medio Rural y Marino, Madrid, Spain, pp. 80.

Anderson HE (1969). Heat transfer and fire spread. Research Paper INT-69, Intermountain Forest and Range Experiment Station, USDA Forest Service, Ogden, UT, USA, pp. 23. [online] URL: http://www.fs.fed.us/rm/pubs_int/int_rpo 69.pdf

Arpaci A, Eastaugh CS, Vacik H (2013). Selecting the best performing fire weather indices for Austrian ecozones. Theoretical and Applied Climatology 114 (3/4): 393-406. - doi: 10.1007/s007 04-013-0839-7

Barriopedro D, Fischer EM, Luterbacher J, Trigo RM, García-Herrera R (2011). The hot summer of 2010: redrawing the temperature record map of Europe. Science 332: 220-224. - doi: 10.1126/ science.1201224

Cardil A, Molina DM, Ramirez J, Vega-García C (2013). Trends in adverse weather patterns and large wildland fires in Aragón (NE Spain) from 1978 to 2010, Natural Hazards and Earth System Sciences 13: 1393-1399. - doi: 10.5194/nhess-13-13 93-2013

Cardil A, Eastaugh CS, Molina DM (2014a). Extreme temperature conditions and wildland fires in Spain. Theoretical and Applied Climatology 122: 219-228. - doi: 10.1007/s00704-014-12958

Cardil A, Molina DM, Kobziar LN (2014b). Extreme temperature days and potential impacts in Southern Europe. Natural Hazards and Earth System Sciences 14: 3005-3014. - doi: 10.5194/n hess-14-3005-2014

Castellnou M, Pagés J, Miralles $M$, Piqué $M$
(2009). Tipificación de los incendios forestales de Cataluña. Elaboración del mapa de incendios de diseño como herramienta para la gestión forestal [Wildland fire typologies in Catalonia. Fire mapping design as a tool for forest management]. In: Proceedings of " 5 ' Congreso Forestal Español”. Ávila (Spain), 21-25 Sep 2009. pp. 16. [in Spanish]

Charney JJ, Keyser D (2010). Mesoscale model simulation of the meteorological conditions during the 2 June 2002 Double Trouble State Park wildfire. International Journal of Wildland Fire 19: 427-448. - doi: 10.1071/WF08191

Crimmins MA (2006). Synoptic climatology of extreme fire - weather conditions across the southwest United States. International Journal of Climatology 26: 1001-1016. - doi: 10.1002/joc. 1300

Diffenbaugh NS, Pal JS, Giorgi F, Gao X (2007). Heat stress intensification in the Mediterranean climate change hotspot. Geophysical Research Letters 34: L11706. - doi: 10.1029/2007GL 030000

Duane $A$, Pique $M$, Castellnou $M$, Brotons $L$ (2015). Predictive modelling of fire occurrences from different fire spread patterns in Mediterranean landscapes. International Journal of Wildland Fire 24 (3): 407-418. - doi: 10.1071/WF 14040

Eastaugh CS, Vacik H (2012). Fire size/frequency modelling as a means of assessing wildfire database reliability. Austrian Journal of Forest Science 129 (3/4): 228-247. [online] URL: http:// epubs.scu.edu.au/esm_pubs/1927/

Flannigan MD, Krawchuk MA, De Groot WJ, Wotton BM, Gowman LM (2009). Implications of changing climate for global wildland fire. International Journal of Wildland Fire 18: 483-507. doi: 10.1071/WFo8187

García-Ortega E, Trobajo MT, López L, Sánchez JL (2011). Synoptic patterns associated with wildfi res caused by lightning in Castile and Leon, Spain. Natural Hazards and Earth System Sciences 11: 851-863. - doi: 10.5194/nhess-11-8512011

Giannakopoulos C, Le Sager P, Bindi M, Moriondo $M$, Kostopoulou E, Goodess CM (2009). Climatic changes and associated impacts in the Mediterranean resulting from a $2{ }^{\circ} \mathrm{C}$ global warming. Global Planet Change 68: 209-224. doi: 10.1016/j.gloplacha.2009.06.001

Giorgi F, Lionello P (2008). Climate change projections for the Mediterranean region. Global Planet Change 63: 90-104. - doi: 10.1016/j.glo placha.2007.09.005

Giorgi F (2006). Climate change hot-spots. Geophysical Research Letters 33, L08707. - doi: 10.1029/2006GL025734

Heim RR (2002). A review of twentieth-century drought indices used in the United States. Bulletin of the American Meteorological Society 83: 1149-1165. - doi: 10.1175/1520-0477(2002)083 <1149:AROTDI>2.3.CO;2

Kalnay E, Kanamitsu $M$, Kistler R, Collins W, Deaven D, Gandin L, Iredell M, Saha S, White G, Woollen J, Zhu Y, Chelliah M, Ebisuzaki W, Higgins W, Janowiak J, Mo KJ, Ropelewski C, Wang J, Leetmaa A, Reynolds R, Jenne R, Joseph D (1996). The NCEP/NCAR 40-year reanalysis project. Bulletin of the American Meteorological Society 77: 437-471. - doi: 10.1175/1520-0477 
(1996)077<0437:TNYRP>2.0.CO;2

Lázaro MA (2014). Análisis meteorológico de incendios históricos para la determinación y seguimiento diario de los incendios tipo en Aragón [Analysis of historical fire weather for determining and monitoring daily fire typologies in Aragón]. Msc Thesis, Escuela Técnica Superior de Ingeniería Agraria, Lleida, Spain, pp. 91. [in Spanish]

Lázaro-Palacios MA, Cortés-Rabinad FC, Hernández-Villamayor R, López-del-Río R, Martín-Martín $V$ (2016). Meteorología sinóptica y comportamiento del fuego en Aragón [Synoptic meteorology and fire behavior in Aragon]. Dirección General Gestión Forestal, Caza y Pesca, Gobierno de Aragón, Zaragoza, Spain, pp. 72. [in Spanish] [online] URL: http://goo.gl/IWFXA2 Lecina-Diaz J, Alvarez A, Retana J (2014). Extreme fire severity patterns in topographic, convective and wind-driven historical wildfires of Mediterranean pine forests. PLoS ONE 9 (1): e85127. - doi: 10.1371/journal.pone.0085127 Millán MM, Estrela MJ, Badenas C (1998). Meteorological processes relevant to forest fire dynamics on the Spanish Mediterranean coast. Journal of Applied Meteorology 37: 83-100. doi: 10.1175/1520-0450(1998)037<0083:MPRTF F>2.0.CO;2

Minnesota Department of Natural Resources (2013). Fire danger indexes, Canadian Model. Web site. [online] URL: http://www.dnr.state. mn.us/forestry/fire/maps/fdi_canadian.html Miralles M, Kraus D, Molina DM, Loureiro C, Delogu G, Ribet N, Vilalta O (2010). Improving sup- pression fire capacity. Research Report, European Forest Institute, EFI, Joensuu, Finland, pp. 203-215. [online] URL: http://s3.amazonaws. com/academia.edu.documents/45688063/

Moriondo M, Good P, Durao R, Bindi M, Giannakopoulos C, Corte-Real J (2006). Potential impact of climate change on fire risk in the Mediterranean area. Climate Research 31: 8595. - doi: $10.3354 / \mathrm{cro3} 1085$

Ogi M, Yamazaki K, Tachibana Y (2005). The summer northern annular mode and abnormal summer weather in 2003. Geophysical Research Letters 32: L04706. - doi: 10.1029/2004 GLo21528

Pereira MG, Malamud BD, Trigo RM, Alves PJ (2011). The history and characteristics of the 1980-2005 Portuguese rural fire database. Natural Hazards and Earth System Sciences 11: 3343-3358. - doi: 10.5194/nhess-11-3343-2011 Regato P (2008). Adapting to global change: Mediterranean forests. IUCN Centre for Mediterranean Cooperation, Malaga, Spain, pp. 254 Rothermel RC (1983). How to predict the spread and intensity of forest and range fires. General Technical Report INT-143, Intermountain Forest and Range Experiment Station, USDA Forest Service, Ogden, UT, USA, pp. 161. [online] URL: http://digitalcommons.usu.edu/cgi/viewcontent .cgi?article $=1063 \&$ context $=$ barkbeetles

Salis M, Ager AA, Arca B, Finney MA, Bacciu V, Duce P, Spano D (2013). Assessing exposure of human and ecological values to wildfire in Sardinia, Italy. International Journal of Wildland Fire 22: 549-565. - doi: 10.1071/WF11060
San Miguel-Ayanz J, Schulte E, Schmuck G, Camia $A$ (2013). The European Forest Fire Information System in the context of environmental policies of the European Union. Forest Policy and Economics 4: 19-25. - doi: 10.1016/j.forpol.20 11.08.012

Trigo RM, García-Herrera R, Díaz J, Trigo IF, Valente MA (2005). How exceptional was the early August 2003 heatwave in France? Geophysical Research Letters 32: L10701. - doi: 10.1029/2005GL022410

Trouet V, Taylor AH, Carleton AM, Skinner CN (2009). Interannual variations in fire weather, fire extent, and synoptic - scale circulation patterns in northern California and Oregon. Theoretical and Applied Climatology 95: 349-360. doi: 10.1007/s00704-008-0012-x

Turco M, Llasat MC, Von Hardenberg J, Provenzale A (2014). Climate change impacts on wildfires in a Mediterranean environment. Climatic Change 125 (3-4): 369-380. - doi: 10.1007/s10584014-1183-3

Turner JA (1972). The drought code component of the Canadian forest fire behavior system. Publication no. 1316, Environment Canada, Canadian Forestry Service, Ottawa, Canada, pp. 14. [online] URL: http://www.cfs.nrcan.gc.ca/ pubwarehouse/pdfs/28538.pdf

Vega-García C, Chuvieco E (2006). Applying local measures of spatial heterogeneity to LandsatTM images for predicting wildfire occurrence in Mediterranean landscapes, Landscape Ecology 21: 595-605. - doi: 10.1007/s10980-005-4119-5 